\title{
Anaerobic/oxic Treatment of Slurry-type Swine Waste
}

\author{
Chul Hee Won and Jay Myoung $\operatorname{Rim}^{\dagger}$
}

Department of Environmental Engineering, Kangwon National University, Korea

Received July 2008, accepted September 2008

\begin{abstract}
This paper presents the experimental results in five months operation from a combined anaerobic/oxic system treating swine waste with average concentrations in organic matter and nitrogen of 7,930 mgCOD/L and $671 \mathrm{mgTKN} / \mathrm{L}$, respectively. The system was formed using an upflow anaerobic sludge blanket (UASB) reactor and oxic reactor connected in series with a recycling line of oxic effluents to UASB for its denitrification. The UASB reactor was operated at an organic volumetric loading rate (VLR) of $2.1 \sim 4.5 \mathrm{kgTCOD} / \mathrm{m}^{3} /$ day and the removal efficiency of TCOD was $66.3 \sim 85.4 \%$. The overall removal efficiency of TCOD was more than 99\%. The oxic reactor was operated at a nitrogen VLR of $0.10 \sim 0.20 \mathrm{kgTKN} /$ $\mathrm{m}^{3} /$ day and the nitrification efficiency was $75 \%$. However, the complete denitrification was observed in the UASB reactor that was due to the optimal temperature and sufficient carbon source. The overall removal rate of TN was about $80 \%$. About $76.2 \%$ of the influent COD mass was accountable in a COD mass balance at a level of VLR $3.64 \mathrm{kgCOD} / \mathrm{m}^{3} /$ day. The production rate of methane was $0.32 \mathrm{LCH}_{4} / \mathrm{gCOD}_{\text {removed }}$ when influent organics, VLR, were recorded by $3.4 \sim 4.5 \mathrm{kgCOD} / \mathrm{m}^{3} /$ day.
\end{abstract}

Keywords: Denitrification, Methane, Nitrification, Swine waste, UASB

\section{Introduction}

A UASB reactor has been used increasingly in recent years to treat various industrial and municipal wastes. ${ }^{1,2)}$ Moreover, as the UASB process contains granules, swine waste can be treated using this process. ${ }^{3)}$ However, anaerobic digestion has proved to be highly efficient in the removal of organic matter but is inherently inadequate for nutrient removal. Therefore, the posttreatment of anaerobic process effluent appears to be mandatory in most situations. In particular, nitrification and denitrification steps are necessary to after anaerobic treatments for nitrogen removal. Furthermore, anaerobic digestion requires the introduction of anaerobic/aerobic steps or a chemical process for phosphorus removal. In particular, in the case of the slurry-type swine wastewater, a nutrient removal process is necessary to after anaerobic digestion because it contains a high concentration of nutrients. These process configurations and operation models have been tested for the removal of organic and nitrogen removal from landfill leachate..$^{4-9)} \mathrm{Im}$ et al. ${ }^{8)}$ used an anaerobic-aerobic system including simultaneous methanogenesis and denitrification for the treatment of leachate using an upflow anaerobic biofilm reactor and aerobic-activated sludge reactor.

\footnotetext{
+ Corresponding author

E-mail: jmrims@kangwon.ac.kr

Tel: +82-33-250-6352, Fax: +82-33-254-6357
}

This paper presents and discusses the results of the experiment in a lab-scale system composed of a UASB reactor followed by oxic reactor treating swine waste. The main of the research was to investigate the technical feasibility of the UASB/oxic system for organic matter removal and nutrients.

\section{Material and Methods}

\subsection{Swine Waste and Granular Sludge}

This study used swine waste from a waste storage tank. The concentrations of ammonium nitrogen $\left(\mathrm{NH}_{4}{ }^{+} \mathrm{-}\right)$ and total solids (TS) were $5,350 \mathrm{mg} / \mathrm{L}$ and $89,170 \mathrm{mg} / \mathrm{L}$, respectively. These concentrations were too high to examine directly. Thus, the swine waste was diluted by ten times of its origin using distilled water. Table 1 represents the characteristics of the swine waste used in this study.

Non-biodegradable COD (NBDCOD) was estimated by excluding BODu from TCOD and the fraction of NBDCOD was estimated based on TCOD and NBDCOD. NBDCOD was estimated to be $7 \%$ of TCOD. After filtering out swine waste, we have measured BODu of soluble fraction and calculated the soluble and particulate portions of NBDCOD. The particulate and soluble portions were $76.6 \%$ and $23.4 \%$, respectively. Thus, it was determined that $425 \mathrm{mg} / \mathrm{L}$ particulate COD and $130 \mathrm{mg} / \mathrm{L}$ solu- 
ble COD could not be removed using a biological manner. The total kjeldahl nitrogen (TKN) of swine waste was composed of $78 \%$ ammonium nitrogen and $22 \%$ organic nitrogen. The ratio of influent $\mathrm{PO}_{4}$-P/TP was operated within a range of $0.12 \sim 0.30$ (average 0.20 ), and the percentage of particulate phosphorus was $78 \%$. Particulate phosphorous has been calculated after excluding dissolved phosphorous from total phosphorous. The TCOD/TKN ratio of influent wastewater was in the range of 9.2 14.8 (average 11.8) and the carbon source for the denitrification was sufficient.

The UASB reactor was inoculated with $2 \mathrm{~L}$ of granular sludge from an anaerobic reactor used to treat the swine waste.

\subsection{Experimental Equipment Setup and Operation}

The laboratory-scale equipment used in this study consisted of two reactors. The flow chart of the reactors is shown in Fig. 1. The UASB reactor with an internal diameter of $70 \mathrm{~mm}$ and a height of 1,000 mm was used. The UASB reactor included a Gas solid Separator (GSS) equipment, which separates sludge from gas, and was equipped with a gas outlet. Influent wastewater was fed into the reactor through a feed distributor using a masterflux pump (USA). The outlet gas was collected using a gas collector and its composition $\left(\mathrm{CH}_{4}\right.$ and $\mathrm{CO}_{2}$ contents, \%) was analyzed using an Infrared Gas Analyze Instrument (model GA 94A, U.K). The temperature of the reactor was controlled at $35 \pm 1^{\circ} \mathrm{C}$ by a thermostat connected to the water jacket of the reactor.

After installing the UASB reactor, an oxic reactor was placed. The oxic reactor and a settling tank of sufficient volume were $16 \mathrm{~L}$ and $4 \mathrm{~L}$, respectively. For a denitrification process, the effluent of settling tank was recycled into the UASB reactor.

The mixed liquor volatile suspended solid (MLVSS) concentration for the oxic reactor was between 1,770 and 2,014 mg/L and the solid retention time (SRT) was controlled over 25 days. The hydraulic retention time (HRT) was 2.5 and 8 days (based on the influent flow) in the UASB and aerobic step, respectively. Table 2 shows the operating condition of this system (UASBOxic process).

Table 2. Operational conditions of UASB-Oxic process

\begin{tabular}{lcc}
\hline Item & UASB & Oxic \\
\hline Reactor volume (L) & 5 & 16 \\
HRT (days) & 2.5 & 8 \\
Nitrate recycle ratio & - & $1 \mathrm{Q}$ \\
Sludge recycle ratio & - & $0.5 \mathrm{Q}$ \\
Organic VLR $\left(\mathrm{kgCOD} / \mathrm{m}^{3} / \mathrm{d}\right)$ & $2.1 \sim 4.5$ & - \\
Nitrogen VLR $\left(\mathrm{kgTKN} / \mathrm{m}^{3} / \mathrm{d}\right)$ & $0.20 \sim 0.36$ & - \\
Temperature $\left({ }^{\circ} \mathrm{C}\right)$ & $35 \pm 1$ & $21 \sim 32$ \\
\hline
\end{tabular}

Table 1. Chemical properties of swine waste

\begin{tabular}{|c|c|c|}
\hline \multirow{2}{*}{ Item } & \multicolumn{2}{|c|}{ Influent waste water } \\
\hline & Range & Average \pm S.D $(\mathrm{N}=40)$ \\
\hline $\mathrm{pH}$ & $6.49 \sim 7.36$ & $6.84 \pm 0.24$ \\
\hline $\mathrm{TS}, \mathrm{mg} / \mathrm{L}$ & $7,268 \sim 12,492$ & $8,917 \pm 1,374.4$ \\
\hline $\mathrm{TCOD}_{\mathrm{Cr}}, \mathrm{mg} / \mathrm{L}$ & $5,310 \sim 11,180$ & $7,930 \pm 1,019.9$ \\
\hline $\mathrm{SCOD}_{\mathrm{Cr}}, \mathrm{mg} / \mathrm{L}$ & $2,080 \sim 5,010$ & $3,414 \pm 100.3$ \\
\hline TKN, mg/L & $497 \sim 897$ & $671 \pm 112.7$ \\
\hline $\mathrm{PO}_{4}-\mathrm{P}, \mathrm{mg} / \mathrm{L}$ & $18.6 \sim 57.6$ & $34.5 \pm 12.4$ \\
\hline Alkalinity, mg/L (as $\mathrm{CaCO}_{3}$ ) & $1,654 \sim 4,375$ & $2,854 \pm 973.3$ \\
\hline TCOD/TKN & $9.2 \sim 14.8$ & $11.8 \pm 1.5$ \\
\hline
\end{tabular}

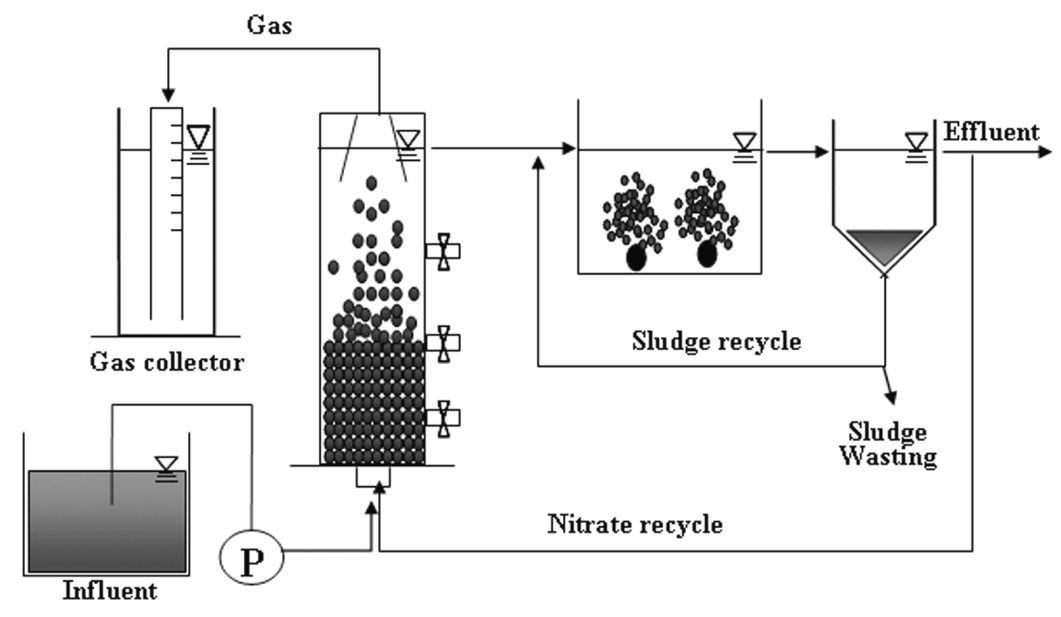

Fig. 1. Schematic diagram of UASB- Oxic process. 


\section{Results and Discussion}

\subsection{Removal of Organic Matter}

The UASB reactor could be operated for high-rate organics VLR. Won et al. ${ }^{3)}$ have reported that when swine waste is used as a substrate, the UASB reactor can be operated for high organics VLR of $10 \mathrm{kgTCOD} / \mathrm{m}^{3} /$ day. However, in this study, the UASB reactor was operated ranged from 2.1 to $4.5 \mathrm{kgTCOD} /$ $\mathrm{m}^{3} /$ day organics VLR in order to reduce organic VLR in the nitrification reactor. Then, the organics VLR for the overall process was operated at a rate of $0.51 \sim 1.06 \mathrm{kgTCOD} / \mathrm{m}^{3} /$ day.

Fig. 2 shows the effluent concentration at each stage in the entire process and total removal efficiency of COD. In this study, the VLR was increased not by varying the HRT, but by increasing the influent concentration. As the VLR increased, the effluent concentration of COD (TCOD and SCOD) gradually increased, but the removal efficiency of COD was stabilized by the characteristics and activity of the granular sludge. Within the VLR range (UASB reactor), the removal efficiency of TCOD was ranged from 66.3 to $85.4 \%$. However, the overall effluent concentration of TCOD (UASB-Oxic) was $608 \mathrm{mg} / \mathrm{L}$ and the removal efficiency of TCOD was $92.0 \%$.

Fig. 3 shows the effluent concentration and total removal efficiency of COD with an average organic VLR. It indicates that most of the organic materials removed from the UASB reactor during the operation period. We speculate that the high removal efficiency in the anaerobic reactor was due to the high microbial activity of the granule sludge. We also suggest that organic materials in the anaerobic zone was removed by the uptake of organic carbon along with the denitrification of the nitrified effluent from the settling tank.

As the organic VLR increased, the removal efficiency of TCOD gradually increased, but the removal efficiency of SCOD

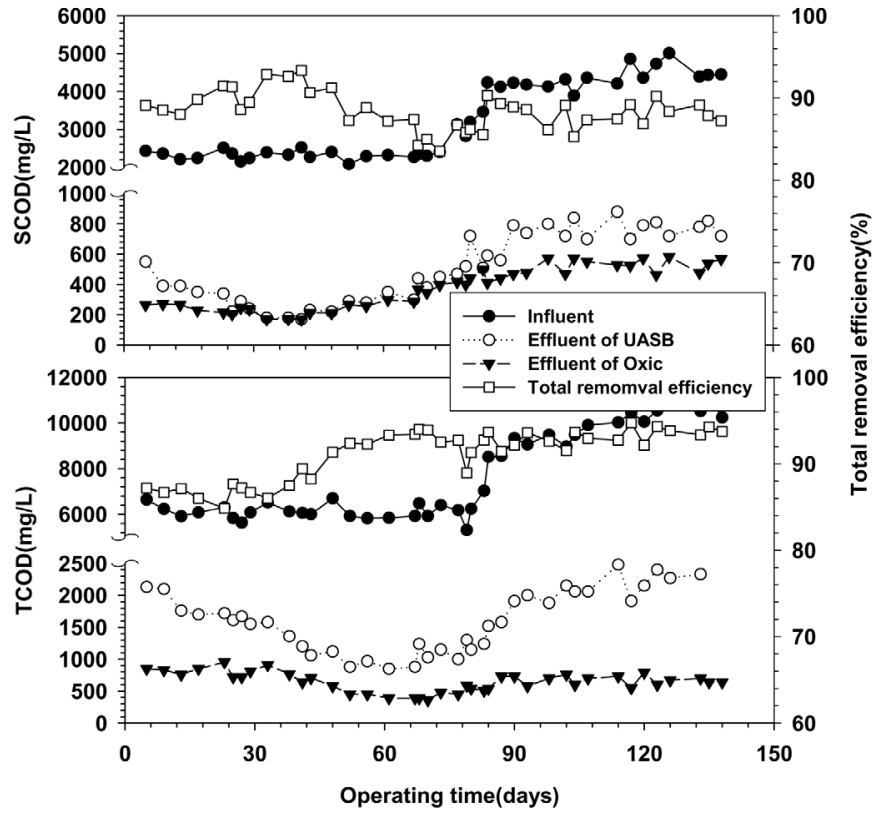

Fig. 2. Variations of COD concentrations and total removal efficiencies with operating time.

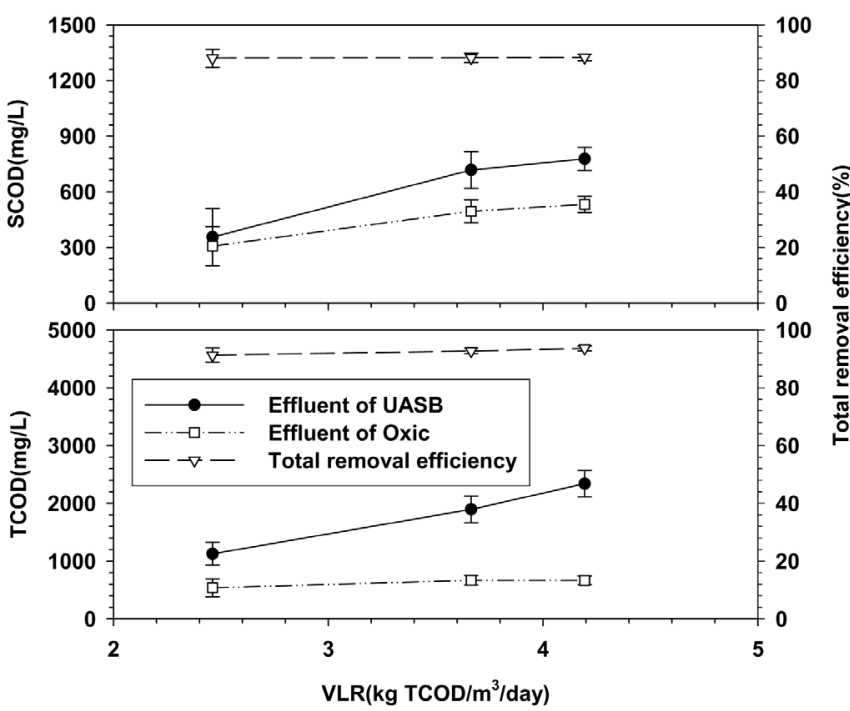

Fig. 3. Effluent COD concentrations and total removal efficiencies with VLR.

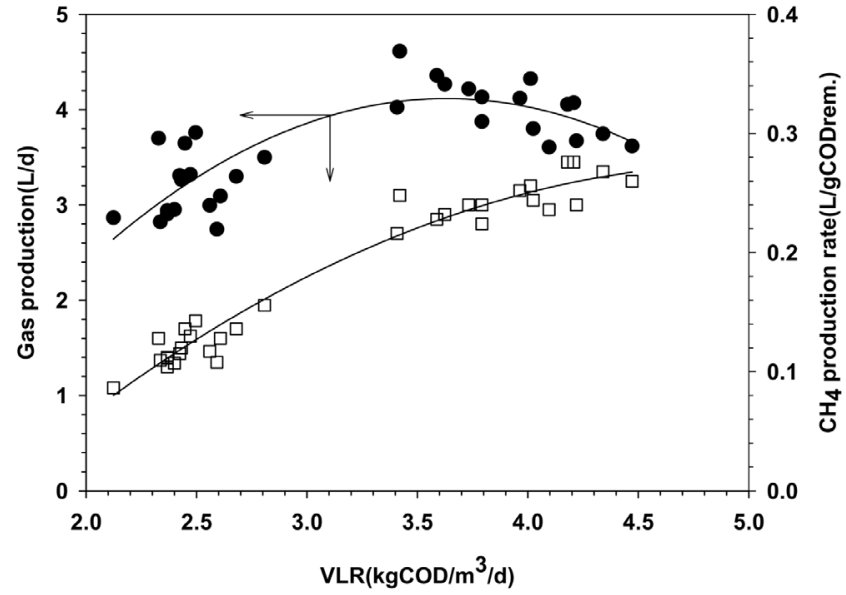

Fig. 4. Gas and $\mathrm{CH}_{4}$ production rate with VLR in UASB reactor.

decreased. The overall organic VLR was obtained by the total removal efficiency of $91 \sim 94 \%$ for the TCOD. In addition, the removal efficiency of SCOD was $88 \%$ approximately. Considering that the concentration of inflow waste was $555 \mathrm{mg} / \mathrm{L}$, the values $306.2 \sim 531.8 \mathrm{mg} / \mathrm{L}$, the measured effluent SCOD concentration from the settling tank, was considered as NBDCOD.

The rate of methane gas production in the UASB reactor was estimated on the basis of the gas production rate versus VLR as shown in Fig. 4. The rate of methane production was $0.32 \mathrm{LCH}_{4} /$ gTCOD $_{\text {removed }}$ when influent organics VLR were determined as $3.4 \sim 4.5 \mathrm{kgTCOD} / \mathrm{m}^{3} /$ day at a mass balance. In this study, the gas content was determined for the whole period and the average percentage of $\mathrm{CH}_{4}$ was about $76 \%$. However, the percentage of $\mathrm{N}_{2}$ in the gas was lower than $1 \%$. The percentage of $\mathrm{CO}_{2}$ was maintained at around $20 \%$. According to the results, it can be seen that the recycling of the effluent oxic reactor and denitrificaiton in the UASB reactor did not affect the gas quality.

\subsection{Removal of Nitrogen}

Fig. 5 shows the variation in the total concentration of $\mathrm{NH}_{4}{ }^{+}-$ 


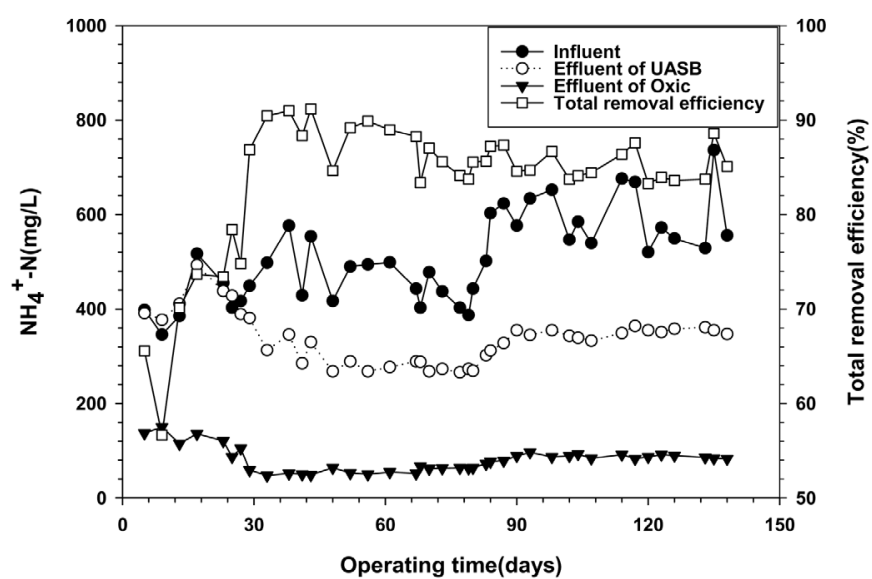

Fig. 5 . $\mathrm{NH}_{4}{ }^{+}-\mathrm{N}$ concentration with operating time.

$\mathrm{N}$ during the operating period. The concentration of the influent $\mathrm{NH}_{4}{ }^{+}$-N was lower than a level which can inhibit anaerobic bacteria in the UASB reactor. In general, the $\mathrm{NH}_{4}{ }^{+}-\mathrm{N}$ in the UASB reactor rather increased, or decreased more or less, but the concentration of the $\mathrm{NH}_{4}{ }^{+}-\mathrm{N}$ in the UASB reactor was low because of the recycled effluent, and most of the $\mathrm{NH}_{4}{ }^{+}-\mathrm{N}$ removal was performed in the oxic reactor.

Fig. 6 shows the nitrification rate in the oxic reactor with VLR. The average nitrification rate of ammonium nitrogen was about $75 \%$. We speculate that the incomplete nitrification in the oxic reactor was due to the insufficiency of alkalinity. In the oxic reactor, the average influent TKN concentration was $385 \mathrm{mg} / \mathrm{L}$. Therefore, for completing the nitrification, it required a 2,738 $\mathrm{mg} / \mathrm{L}$ of alkalinity as $\mathrm{CaCO}_{3}(7.14 \mathrm{~kg}$ alkalinity per $1 \mathrm{~kg}$ TKN destroyed). In this study, however, the average effluent alkalinity concentration of the UASB reactor was $2,027 \mathrm{mg} / \mathrm{L}$ and the insufficient alkalinity was about $700 \mathrm{mg} / \mathrm{L}$ as $\mathrm{CaCO}_{3}$. Then, the insufficient alkalinity value was approximately consistent with considering the effluent $\mathrm{NH}_{4}{ }^{+}-\mathrm{N}$ concentration of the oxic reactor as shown in Fig. 5. The specific nitrification rate was in the range of $0.024 \sim 0.031$ (avg. 0.028) gN/gVSS/day.

Fig. 7 shows the effluent concentrations of $\mathrm{NOx}-\mathrm{N}, \mathrm{pH}$, and $\mathrm{NO}_{2}-\mathrm{N} / \mathrm{NOx}-\mathrm{N}$ ratios in the final effluent for the UASB-Oxic



Fig. 6. Nitrification rate versus nitrogen loading rate in oxic reactor.

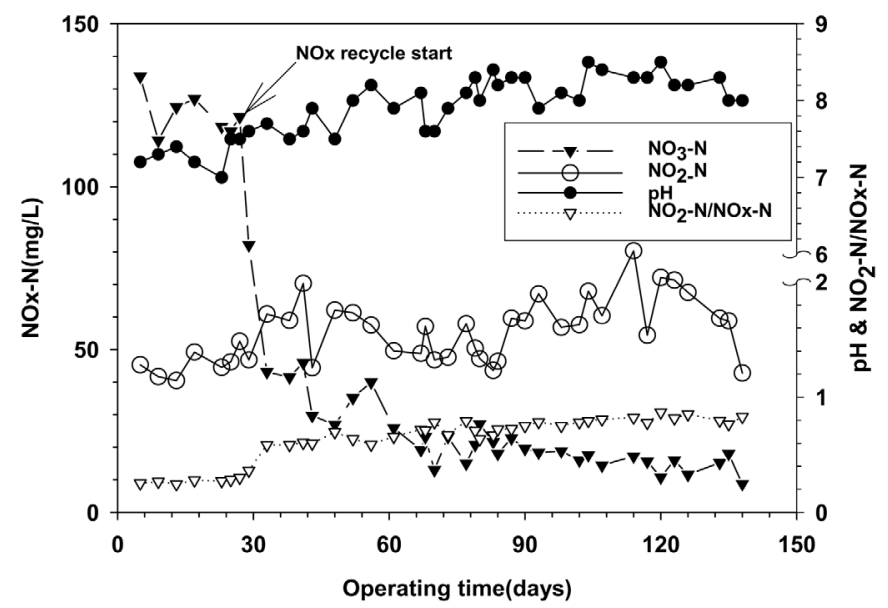

Fig. 7. NOx-N concentration, $\mathrm{pH}$ and $\mathrm{NO}_{2}-\mathrm{N} / \mathrm{NOx}-\mathrm{N}$ ratio with operating time.

process. The concentration of $\mathrm{NO}_{2}-\mathrm{N}$ and $\mathrm{NO}_{3}-\mathrm{N}$ were maintained at approximate levels of $50 \mathrm{mg} / \mathrm{L}$ and $120 \mathrm{mg} / \mathrm{L}$ for 30 days, respectively, and the ratio of $\mathrm{NO}_{2}-\mathrm{N} / \mathrm{NOx}-\mathrm{N}$ was lower than 0.5 . After 30 days, the $\mathrm{NO}_{3}-\mathrm{N}$ concentration sharply decreased because of the recycle of the final effluent from the settling tank to the UASB reactor. This indicated that the denitrification reaction was achieved in the UASB reactor. After 30 days, the concentration of the $\mathrm{NO}_{2}-\mathrm{N}$ was ranged from $42.8 \sim 80.3 \mathrm{mg} / \mathrm{L}$ and the ratio of $\mathrm{NO}_{2}-\mathrm{N} / \mathrm{NOx}-\mathrm{N}$ gradually increased over time.

Sometimes the swine waste causes an nitrite accumulation due to obstruction of nitrification by free ammonia (FA) in an oxic reactor. ${ }^{10)}$ Randall and Buth ${ }^{11)}$ reported that a nitrite buildup was the results of the sensitivity of nitrite oxidizers to environmental factors, such as temperature, $\mathrm{pH}$, and dissolved oxygen (DO) concentration. In this study, the nitrite accumulation have happened to the oxic reactor in spite of the low influent $\mathrm{NH}_{4}{ }^{+}-\mathrm{N}$ VLR. It was demonstrated that a high level of $\mathrm{pH}$ plays an important role in a nitrification step. As shown in Fig. 7, the $\mathrm{pH}$ of the effluent in the oxic reactor was 7.0 8.5 (average 7.9). The results were in accord with those of Villaverde et al... ${ }^{12}$

Fig. 8 shows the NOx-N removal efficiency versus that of NOx-N loading rate in the UASB reactor. The UASB reactor was operated at a ratio of 50 200 C/Nitrate and the removal efficiency of NOx-N was more than $99 \%$. It was considered that the dissimilatory nitrate reduction to ammonium (DNRA) did not occurred. Akunna et al. ${ }^{13)}$ reported that DNRA was a pathway in the nitrate reduction with glucose as a carbon source and the denitrification occurred when acetate was used as an external carbon source. Also they mentioned that denitrification reaction occurred at a ratio of C/Nitrate below 53, but DNRA could occur at a ratio of C/Nitrate above $53 .{ }^{14)}$ In this study, DNRA did not occur in spite of the high C/Nitrate ratio. This result was considered to be due to the enough VFA concentration of slurry-type swine waste. ${ }^{3)}$ Thus, we speculated that the high denitrification rate was due to the denitritation performed at optimal denitrification conditions $\left(35^{\circ} \mathrm{C}\right.$, internal carbon source) in the UASB reactor. Consequently, a high rate of denitrification and organic removal was achieved by recycling of the effluent into the UASB reactor. 


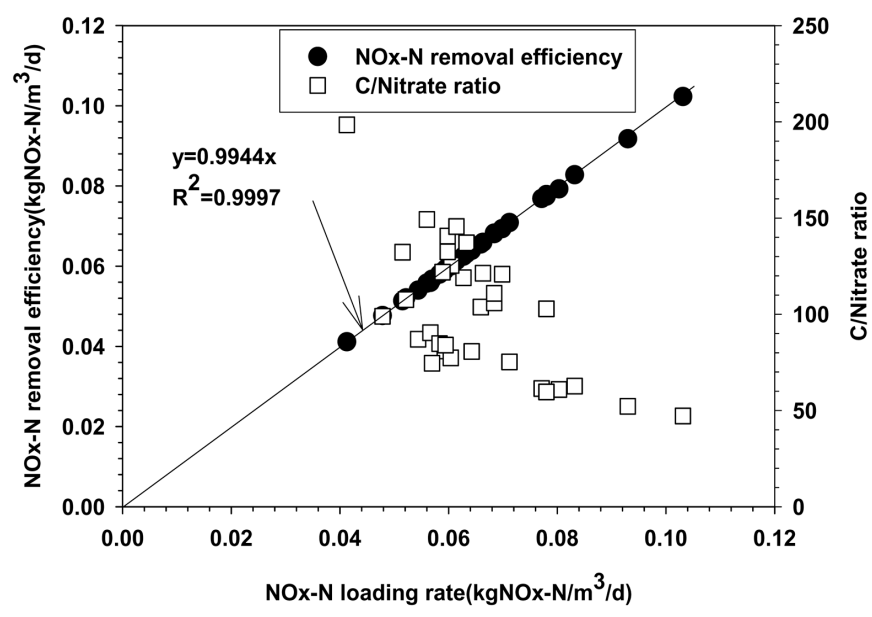

Fig. 8. NOx-N removal rate versus NOx-N loading rate in the UASB reactor.



Fig. 9. Relationship of removed NOx-N and SCOD.

Fig. 9 shows the removal efficiency of organic carbon accompanied with the denitrification in the UASB reactor. In general, the process of the denitrification requires external organic carbon sources including methanol and acetate. Barnes ${ }^{15)}$ have reported that when methanol is used as a organic carbon source, the denitrification of $1 \mathrm{mg}$ of $\mathrm{NO}_{3}-\mathrm{N}$ requires $2.47 \mathrm{mg}$ of methanol that can be equivalent to $3.7 \mathrm{mg}$ of COD. In this study, the influent was utilized as the internal carbon source for the denitrification. This resulted in the complete denitrification during the operating period while no external carbon sources were supplied.

As shown in the literature (Fig. 10), the TN removal efficiency depended on the influent TCOD/TN ratios and shape of the reactor. In a sequencing batch reactor (SBR), over $80 \%$ of the TN removal rate was observed at a TCOD/TN ratio more than 3.9. $\mathrm{Han}^{10)}$ reported that the TN removal rate was $69.3 \sim 78.5 \%$ at a TCOD/TN range of $4.5 \sim 5.8$. In this study, a $79.5 \sim 80.5 \%$ of the total TN removal rate was achieved within a TCOD/TN range of 10.1 12.6. We speculate that a low TN removal rate was insufficient for the nitrification and few nitrifies were presented in the oxic reactor. ${ }^{22)}$

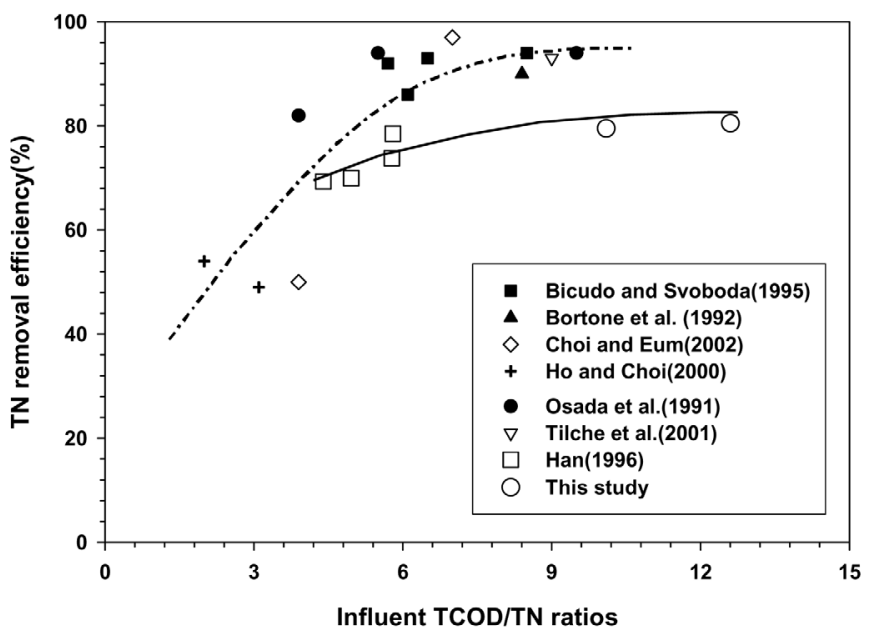

Fig. 10. TN removal efficiencies with TCOD/TN ratios. ${ }^{10,16-21)}$

\subsection{Removal of Phosphorus}

Fig. 11 shows the concentration change in the influent and effluent of phosphorus versus operation time. The data shows that the total phosphorus (TP) was removed from the UASB reactor with anaerobic and anoxic conditions. This was due to the fact that the swine waste is composed of a large amount of granule phosphorus so that the phosphorus was removed by physical adsorption and trapping in the reactor. Total removal of TP was in the range of $45 \sim 67 \%$. However, the removal rate of $\mathrm{PO}_{4}-\mathrm{P}$ was 15 56 (37) \%.

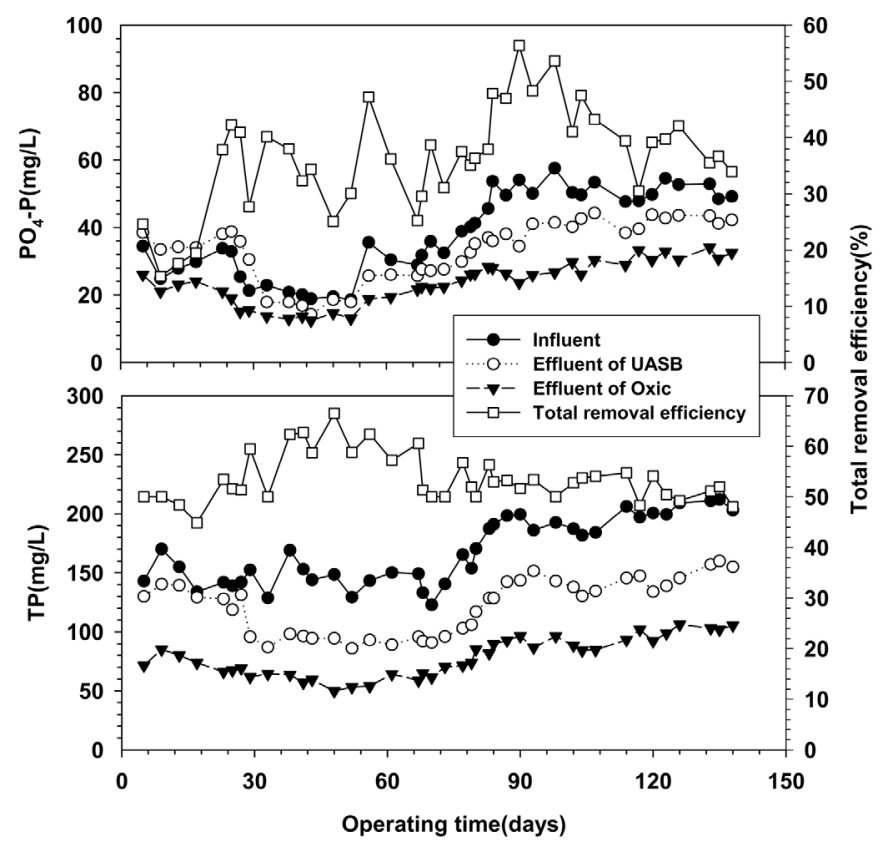

Fig. 11. Phosphorus concentrations and total removal efficiency with operating time.

\subsection{COD Mass Balance}

In each process of the treatment processes employed in this study, the mass balance can be accounted for as follows. In the 
Table 3. Results of COD mass balance calculation in UASB-Oxic process

\begin{tabular}{ll}
\hline Items & Value \\
\hline Input COD mass, mgCOD/d & $19,648(100 \%)$ \\
Output COD mass, mgCOD/d & $14,978(76.2 \%)$ \\
Effluent COD mass & $1,620(8.2 \%)$ \\
Wasting COD mass & $1,747(8.9 \%)$ \\
Oxidized COD mass in oxic reactor & $3,903(19.9 \%)$ \\
Denitrification COD mass in UASB reactor & $400(2 \%)$ \\
Methane conversion COD mass in UASB reactor & $7,308(37.2 \%)$ \\
\hline
\end{tabular}

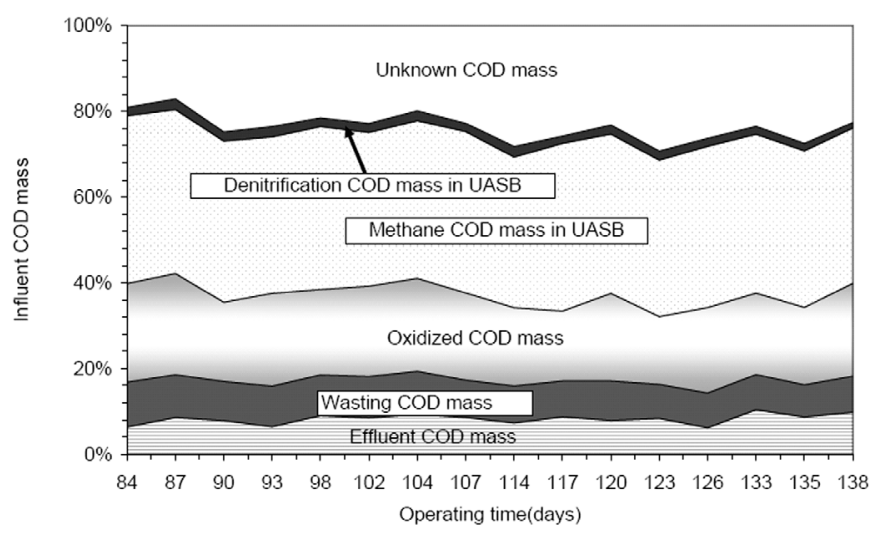

Fig. 12. COD mass balance.

UASB reactor, organic materials can be used to the cell synthesis of anaerobic bacteria, denitrification, and its conversion to methane. In an aerobic reactor, organic materials may be consumed by cell synthesis and oxidation processes for metabolic energy. A mass balance was calculated using the data collected for 54 days over 2.5 days of HRT and 3.64 ( 0.87 based on total process) $\mathrm{kgCOD} / \mathrm{m}^{3} /$ day VLR (based on UASB reactor).

Table 3 and Fig. 12 represent the COD mass balance. In this study, $76.2 \%$ of the input COD mass was explainable in the COD mass balance. Under this condition, the conversion to methane in the UASB reactor accounted for a $37.2 \%$ of the total COD mass and $2 \%$ of denitrification COD mass. Cell synthesis and conversion to energy in the aerobic reactor accounted for $19.9 \%$, and it indicated that organic materials from the preceding reactor were limited, and the limitation was beneficial for the nitrification. Waste and effluent COD mass were recorded as less than $10 \%$.

\section{Conclusions}

In this study, anaerobic/oxic treatment of swine waste in a sequential two-step UASB/Oxic reactors was investigated. The UASB/Oxic system was found to be a feasible process for treating the swine waste. A UASB reactor was used with total organic VLR ranging from $2.1 \sim 4.5 \mathrm{kgTCOD} / \mathrm{m}^{3} /$ day. Removal efficiency of TCOD was $66.3 \sim 85.4 \%$.

Oxic reactor was operated within the range of $0.10 \sim 0.20$ $\mathrm{kgTKN} / \mathrm{m}^{3} /$ day, an ammonium nitrogen can be converted to nitrate in the oxic reactor via nitrification. The $\mathrm{NH}_{4}-\mathrm{N}$ removal efficiency of the total system was about $75 \%$, and the denitrifi- cation rate of UASB reactor was 99\%. Total phosphorous removal efficiency was within the range of $45 \sim 67 \%$.

Total COD mass balance was $76.2 \%$ when organics VLR was $3.64 \mathrm{kgTCOD} / \mathrm{m}^{3} /$ day.

\section{Acknowledgements}

This study was supported by Kangwon National University

\section{References}

1. Lettinga, G., Man, A. D., ver der Last, A. R. M., Wiegant, W., Frijins, J., and van Buuren, J. C. L., "Anaerobic treatment of domestic sewage and wastewater," Wat. Sci. Tech., 27, 67-73 (1993).

2. Fang, H. H. P., Chui, H. K., Li, Y. Y., and Chen, T., "Effect of degradation kinetics on the microstructure of anaerobic biogranules,” Wat. Sci. Tech., 32, 165-172 (1995).

3. Won, C. H., Kim, B. U., Han, D. J., and Rim, J. M., "The treatment of slurry-type swine waste using UASB reactor," Journal of Korean Society on Water Quality, 20(6), 583588 (2004).

4. Castillo, E., Vergara, M., and Moreno, Y., "Landfill leachate treatment using a rotating biological contactor and an upwardflow anaerobic sludge bed reactor," Waste Manage., 27, 720-726 (2007).

5. Chen, S., Sun, D., and Chung, J. S., "Simultaneous removal of COD and ammonium from landfill leachate using an anaerobic-aerobic moving-bed biofilm reactor system," Waste Manage., 28, 339-346 (2008).

6. He, R., Liu, W. L., Zhang, Z. J., and Shen, D. S., "Characteristics of the bioreactor landfill system using an anaerobicaerobic process for nitrogen removal," Bioresour. Technol., 98, 2526-2532 (2007).

7. Huo, S. L., Xi, B. D., Yu, H. C., Fan, S. L., Su, J., and Liu, H. L., "In situ simultaneous organics and nitrogen removal from recycled landfill leachate using an anaerobic-aerobic process," Bioresour. Technol., 99, 6456-6463 (2008).

8. Im, J. H., Woo, H. J., Choi, M. W., Han K. B., and Kim, C. W., "Simultaneous organic and nitrogen removal from municipal landfill leachate using an anaerobic-aerobic system," Wat. Res., 35(10), 2403-2410 (2001).

9. Yang, Z. and Zhou, S., "The biological treatment of landfill leachate using a simultaneous aerobic and anaerobic (SAA) bio-reactor system," Chemosphere, 72, 1751-1756 (2008).

10. Han, D. J., "Reaction Characteristics of the Development of Biofilm Process Combined Upflow Blanket Filter and Anoxic-Oxic Process for the Nutrient Removal," Ph.D. Thesis, Department of Civil Eng., Kangwon National University, Korea (1996).

11. Randall C. W. and Buth D., "Nitrite build-up in activated sludge resulting from combined temperature and toxicity effect," J. Wat. Pollut. Control Fed., 56, 1045-1049 (1984).

12. Villaverde S., Garcia-Encina, P. A., and Fdz-Planco, F., "Influence of $\mathrm{pH}$ over nitrifying biofilm activity in submerged biofilters,” Wat. Res., 31(5), 1180-1186 (1997). 
13. Akunna, J. C., Bizeau, C., and Moletta R., "Denitrification in anaerobic digesters: possibilities and influence of wastewater COD/N-NOx ratio,” Environ. Technol., 13(9), 825836 (1992).

14. Akunna, J. C., Bizeau, C., and Moletta R., "Nitrate and nitrite reductions with anaerobic sludge using various carbon sources: glucose, glycerol, acetic acid, lactic acid and methanol,” Wat. Res., 27(8), 1303-1312 (1993).

15. Barnes, D. and Bliss, P. J., Biological control of nitrogen in wastewater treatment, E \& F. N. Spon. Ltd., New York, pp. 144 (1983).

16. Bicudo J. R. and Svoboda. O. F., "Intermittent aeration of pig slurry-farm scale experiments for carbon and nitrogen removal," Wat. Sci. Tech., 32(12), 83-90 (1995).

17. Bortone, G., Gemelli, S., Rambaldi, A., and Tilche, A., "Nitrification, denitrification and biological phosphate removal in sequencing batch reactors treating piggery wastewater," Wat. Sci. Tech., 26(5-6), 977-985 (1992).

18. Choi, E. and Eum, Y., "Strategy for nitrogen removal from piggery waste,” Wat. Sci. Tech., 46(6-7), 347-354 (2002).

19. Ho, J. H. and Choi, E., "Nitrogen removal from piggery waste by nitrite nitrification," Proc. of WEFTEC 2000, Anaheim, California, U.S.A., Session 30 (2000).

20. Osada, T., Haga, K., and Harada, Y., "Removal of nitrogen and phosphorus from swine wastewater by the activated sludge units with the intermittent aeration process," Wat. Res., 25(11), 1377-1388 (1991).

21. Tilche, A., Bortone, G., Malaspina, F., Piccinini, S., and Stante, L., "Biological nutrient removal in a full-scale SBR treating piggery wastewater: results and modeling," Wat. Sci. Tech., 43(3), 363-371 (2001).

22. U. S. EPA., Process design manual for nitrogen control, EPA/625/1-77/007 Washington, D. C. (1975). 